\title{
GUIDE TO THE VOLCANIC GEOLOGY OF CHIRICAHUA NATIONAL MONUMENT AND VICINITY, COCHISE COUNTY, ARIZONA
}

By

\author{
John S. Pallister, ${ }^{1}$ Edward A. du Bray, ${ }^{2}$ and Douglas B. Hall ${ }^{3}$
}

Pamphlet to accompany

MISCELLANEOUS INVESTIGATIONS SERIES MAP I-2541

1997

${ }^{1}$ U.S. Geological Survey, Reston, Virginia 20192

${ }^{2}$ U.S. Geological Survey, Denver, Colorado 80225

${ }^{3}$ Department of Geological Sciences, University of Arizona, Tucson, Arizona 85721

Technical terms are shown in italics and defined in the glossary 


\section{CONTENTS}

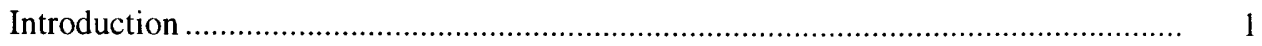

Precambrian Time-Arizona "Arrives" ......................................................................

Paleozoic Time_-"Under the Sea" ............................................................................ 1

Mesozoic Time-_Emergence and Volcanic Eruptions"............................................. 2

Cenozoic Time-Eruption of the Rhyolite Canyon Tuff, Formation of the Turkey Creek Caldera, and Basin and Range Faulting .......................................... 2

Geological Points of Interest in Chiricahua National Monument ................................. 5

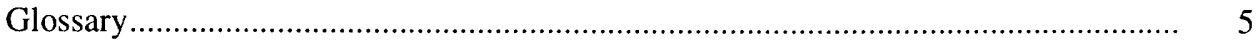

Suggested Additional Reading .............................................................................. 9

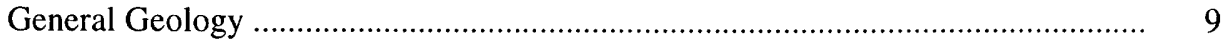

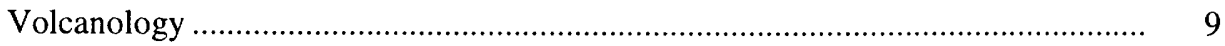

Turkey Creek Caldera ..................................................................................

Appendix - Nontechnical Description of Map Units............................................... 10 


\section{INTRODUCTION}

The geologic history and ancient physical environment of Chiricahua National Monument are revealed by plotting the distribution of different rock types as a geologic map. The map can then be used to infer where ancient landforms (rivers, lakes, and volcanoes) used to be. The age and evolution of these landforms can be determined from examination of their constituent rocks in the field and in the laboratory. We are fortunate because the rocks of southeast Arizona record the natural environment throughout much of earth history. We see evidence that the region was alternately flooded by ancient seas, uplifted along great fault zones, and covered by lava flows, ash, and pumice from volcanoes. The most dramatic geologic event took place 26.9 million years ago when a giant volcanic eruption took place in the mountains just south of the National Monument. So much molten rock was removed from shallow levels of the earth's crust that a 12-mile-diameter "crater" formed as the former mountains collapsed into the void. A crater that forms by collapse is more accurately termed a caldera; in this case it is the Turkey Creek caldera (see accompanying map). This eruption was 1000 times larger than the 1980 eruption of Mount St. Helens and five to ten times the size of the great explosion of Krakatoa in 1883.

Similar and still potentially hazardous volcanoes of this type exist in the United States (for example, within Long Valley, California, and in Yellowstone National Park) and in a number of other places around the Pacific rim; luckily, they erupt infrequently. Yet, the very fact that eruptions are infrequent makes it difficult to predict how and when they will next erupt. This is one of the reasons we study extinct volcanic regions like the Turkey Creek caldera. Because erosion has cut deep valleys into the volcano, we can directly examine parts of the subterranean magma chamber that fed the eruptions, something that is impossible at active, uneroded volcanoes. In this way, we develop and refine a general model for caldera-forming eruptions and we compile a series of "case examples" that allow us to better understand the hazards posed by still-hazardous calderas.

Shortly after eruption, the Turkey Creek caldera was probably similar in appearance to, but twice as large as, the Crater Lake caldera, in Crater Lake National Park, Oregon. Eruptions from the Turkey Creek caldera buried a vast region with a layer of hot ash and pumice, producing a deposit known as tuff. The ash and pumice layer was hot enough to fuse together, or weld. As it cooled, the welded tuff contracted, forming cracks or joints. Water then seeped into the cracks and began eroding out the thousands of rock columns for which the Monument is best known. Assisted by the wedging action of freezing water, stream flow, and erosion by the wind, the cliffs and columns were slowly carved out of the thick layer of welded tuff. We will discuss the volcanic rocks of the National Monument in more detail later, but first we will review the ancient part of the geologic story.

\section{PRECAMBRIAN TIME-ARIZONA "ARRIVES"}

The oldest rock in southeast Arizona is the Pinal Schist. a metamorphic rock that is widely exposed in the Dos Cabezas Mountains, between the National Monument and Willcox, Arizona. The Pinal Schist formed about 1.7 billion years ago during Precambrian time. It is composed of volcanic tuff (much like that in the Monument) and sedimentary rocks. These rocks were metamorphosed into schist as they were heated by masses of molten rock, and as a result of being deeply buried for millions of years. However, at places within the schist we can still recognize pumice blocks in the original volcanic rocks, and grains of sand in the sedimentary rocks. And we can begin to reconstruct the local environment for this ancient period of earth history, a period that pre-dates the development of most life. This appears to have been a time when the Southwest was composed of numerous volcanic belts separated by seas; perhaps, not unlike the western Pacific of today.

These volcanic belts, or island arcs, were made up of low density rocks that floated on heavier and partly molten mantle rocks that moved like a conveyor belt beneath them. The island arcs were swept together and plastered, or accreted, to the edge of North America. This process of continental growth is part of the global process of plate tectonics, a unifying theory that explains many aspects of earth history. As more island arcs were added, the continent grew to the southwest from its previous coastline in Wyoming, such that by 1.4 billion years ago, most of Arizona had been added to North America. About this time, new masses of molten rock intruded into the accreted coastal province, effectively "stitching" it to the mainland. An example of one of these formerly molten rocks is granite, with feldspar crystals an inch or more across, which can be seen in nearby road cuts on Arizona highway 181, about a mile and a half east of the town of Dos Cabezas.

Little of the record remains for what happened during the next 800 million years; presumably many rocks were deposited, but virtually all have been eroded away, leaving an unconformity in the geologic record. This remarkable erosion surface, where 1.4-billion-year-old rocks are separated from 510-570-million-year-old Cambrian rocks, is exposed in road cuts 3.6 miles east of the town of Dos Cabezas. The Cambrian rocks are conglomerate and sandstone, derived from rivers and beaches that record a major advance of the sea, early in Paleozoic time (about 520 million years ago).

\section{PALEOZOIC TIME-"UNDER THE SEA"}

Southeast Arizona was covered by an ancient sea throughout Paleozoic time (570 to about 250 million years ago) and thick layers of limestone and sandstone were deposited. The youngest of these rocks are exposed in the 
northeastern corner of the National Monument, on the rugged southeastern flank of Timber Mountain. Fossil corals, brachiopods (lamp shells), echinoid spines (related to modern sea urchins and sand dollars), and gastropods (snails) are abundant in these rocks and record shallow-water coral reef environments.

\section{MESOZOIC TIME-"EMERGENCE AND VOLCANIC ERUPTIONS”}

Another unconformity, representing a gap of about 150 million years, is in the local geologic record between rocks of Paleozoic and Mesozoic age. The unconformity represents a period of uplift and erosion, such that few rocks of late Paleozoic or early Mesozoic age are preserved in the Chiricahua Mountains. The youngest Paleozoic rock in the area is the Permian Concha Limestone (about 280 million years old), which is overlain by conglomerate, and sandstone of the Cretaceous Bisbee Group (about 100 million years old). Conglomerate beds at the base of the Bisbee Group are widely exposed in the hills east of Whitetail Pass. These beds contain cobbles of fossil-rich limestone that were shed from uplifted mountains composed of the underlying Paleozoic rocks. The conglomerate beds are overlain by fine-grained sedimentary rocks, such as silty limestone, shale, and sandstone, and by lava flows. Some sandstone beds contain fossilized trees (petrified wood); other beds are dark green or gray due to an abundance of dark volcanic rock fragments. Lava that flowed into water-formed pillow-like shapes when the surface of the lava was cooled rapidly by the water, but the interior kept flowing and inflated the rind like a balloon. Such pillow lava can be seen along the road across Onion Saddle, between the National Monument and Portal, Arizona, although it is often difficult to distinguish true pillow forms in these rocks from rounded outcrop blocks produced by weathering. The Bisbee Group rocks record the presence of a shallow inland sea that extended from this region across southern New Mexico and to the Gulf of Mexico.

Numerous volcanoes formed during the Mesozoic Era, as crustal rocks beneath the Pacific Ocean slid under the southwestern United States and melted. Oceanic crustal plates ride on the underlying mantle as it moves like a conveyor belt from spreading ridges to subduction zones. The oceanic crust that is generated at spreading ridges is later destroyed as it is dragged down into the mantle at subduction zones. The continents drift about the globe as a consequence of being caught between the "conveyor belts" of spreading ocean ridges and subduction zones. Continents grow, as bits of the oceanic crust, including islands like Hawaii and island arcs like Japan, are "scraped off" the top of the conveyor belt and accreted to the edges of continents. As described above, this process of continental growth took place in Arizona during Precambrian time, and again in California during Mesozoic time.
Volcanoes form above subduction zones as the oceanic crust is drawn down and heated beneath them. Seawater and other volatile components are "boiled off" in the subduction zone and rise into the overlying hot rocks, where they promote melting, in the same way that addition of a flux allows metals to melt more easily. The melted rock, or magma, is enriched in volatiles and it rises toward the surface. It may ascend directly to the surface and erupt, or it may pond beneath the surface to form subterranean reservoirs of molten rock, known as magma chambers. Magma in chambers cools slowly; it eventually crystallizes to form coarse-grained rocks such as granite. However, while still molten, these chambers may leak magma to the surface above, "feeding" one or more volcanoes. This is the current situation at Mount St. Helens, at Long Valley California, at Yellowstone National Park, and at hundreds of other volcanic fields around the globe. Occasionally, parts of a shallow magma chamber may become unstable and "boil" causing what is, in effect, a huge steam explosion. In this situation, a giant eruption takes place as tens to hundreds of cubic miles of magma are vented within a few hours or days. Caldera-forming eruptions are among the largest and most violent volcanic events known on earth.

Subduction zones underlay this part of Arizona (and the Southwest) during much of the Mesozoic Era. During this period, the Sierra Nevada batholith (including the large granite masses in Yosemite National Park) were intruded, and they fed volcanoes in an arc along the western coast of North America. Huge volcanoes also erupted in southeastern Arizona, first forming calderas in the Huachuca and southern Dragoon Mountains about 160 million years ago, then again during a burst of volcanic activity and faulting at the close of the Mesozoic Era about 65 million years ago. This latter period is known as the Laramide orogeny, an episode of mountain building that occurred throughout the western United States at the end of the Mesozoic. It was during the Laramide orogeny that most of the ores of copper, silver, and gold were deposited in the southwestern United States. Ore that was deposited during this tumultuous period of earth history is mined at many of the open-pit mines in southeast Arizona. Nearby, welded tuff that forms the summit of the Dos Cabezas Mountains was erupted during this period, and mineralizing fluids invaded the surrounding rocks to produce small ore deposits of copper, lead, silver, and gold.

\section{CENOZOIC TIME-ERUPTION OF THE RHYOLITE CANYON TUFF, FORMATION OF THE TURKEY CREEK CALDERA, AND BASIN AND RANGE FAULTING}

The Cenozoic Era of geologic time is divided into two periods: the Tertiary ( 65 million years ago to about 2 million years ago), and the Quaternary (about 2 million years ago to the present). A subduction zone was present beneath the 
southwestern United States during the first half to two thirds of the Tertiary period, so volcanism continued. Most of the volcanic activity in the Chiricahuas took place between about 35 and 25 million years ago. This is an interval when small magma chambers were emplaced and cooled to form granite at Cochise Stronghold (across the Sulphur Springs Valley to the west) and in several areas of the northern Chiricahua Mountains. Scattered volcanoes erupted lava flows during the same interval. Some of these were dark andesite and basalt, such as the rocks exposed in the road cuts uphill from Bonita Park on the road to Sugarloaf Mountain and Massai Point in the National Monument. The red-weathering sedimentary deposits near Bonita Park were laid down along the floor of the ancient National Monument valley about 30 million years ago. Recent study has shown that these beds of sandstone and conglomerate are not "lake beds" as previously thought but were instead deposited by streams.

Other small volcanoes produced viscous rhyolite lava flows that piled up around their eruption vents like toothpaste and formed the hills north and south of Faraway Ranch. A vertical flow ramp where viscous rhyolite lava piled up on itself is clearly visible as vertical layers in the cliff north of the Faraway Ranch parking lot (see figure 6 on the accompanying map). Small explosions accompanied the eruption of rhyolite lava and produced nuée ardente (glowing cloud and avalanche) deposits consisting of thin beds of rhyolite ash and rock debris.

About 26.9 million years ago, a large mass of magma accumulated within a few miles of the surface, forming a magma chamber just south of the National Monument (see block diagram $\mathrm{A}$ on the accompanying map). Eventually, the overlying rock ruptured and the resulting decrease in confining pressure allowed volatiles (mostly water vapor and carbon dioxide) to separate from the magma and form gas bubbles. Foaming magma formed pumice and expanded as much as 50 times in volume, causing a series of large explosive eruptions. The eruptions blew more than 100 cubic miles of magma out of the volcano and buried a region of at least 1,200 square miles in a thick blanket of hot $a s h$ and pumice. For comparison, the 1980 eruption of Mount St. Helens produced only one tenth of a cubic mile of magma and the 1991 eruption of Mount Pinatubo in the Philippines, which was one of the largest eruptions of the century, produced only about one cubic mile of magma. Withdrawal of such a large volume of magma caused the roof of the magma chamber to collapse. The collapse produced a giant crater-like depression, 12 miles in diameter and at least 5,000 feet deep above the magma chamber (see block diagram B on the accompanying map). The depression, named the Turkey Creek caldera, was partly filled with some of the just-erupted ash and pumice. Although large, the Turkey Creek eruption is not the biggest known; individual eruptions of the same type in the San Juan Mountains of Colorado and in Yellowstone National Park each vented more than 500 cubic miles of magma.
Magma from the Turkey Creek volcano was rich in silica (about 77 percent $\mathrm{SiO}_{2}$ ); volcanic rock of this composition is called rhyolite. When bubbles of gas in the magma exploded during the eruption, they liberated gas that propelled ash clouds and pyroclastic flow's. The magma was blown into billions of microscopic shards of volcanic glass and fragments of crystals. Together with microscopic fragments of rock that were caught up in the explosions, these particles are known as volcanic ash. The eruption produced boiling clouds of very hot (greater than $1,000^{\circ} \mathrm{F}$ ) ash, pumice, rock fragments, and gas that were propelled into the atmosphere and across the land surface at speeds of 50 to more than 100 miles an hour, scouring everything in their paths like superheated jets from a sandblaster. As the clouds lost gas and deflated, they became more dense and flowed downslope from the volcano as pyroclastic flow's that ponded in valleys to form thick deposits of steaming ash and pumice. A rock composed mainly of ash and pumice is named tuff. If the deposit is thick and the shards of volcanic glass and the pumice fragments are still hot, they fuse together and compact under their own weight to form a rock called welded tuff.

The National Monument area was formerly a valley (called Monument Valley on block diagram A); it was filled to a depth of at least 1,600 feet by a series of pyroclastic flows during the caldera-forming eruption. Because of the great thickness and dense welding, this valley-filling deposit of tuff has not been eroded away during the past 26.9 million years. The deposit is named Rhyolite Canyon Tuff for the excellent exposures in Rhyolite Canyon. Outcrops of similar rocks that are many miles away and were produced by the same eruption are given the same name. This is the nature of a stratigraphic unit; rocks that were produced at about the same time and are similar in composition are named after places where they are best exposed.

Pumice, ash, rock fragments, and crystals of feldspar and quartz are the main constituents of the Rhyolite Canyon Tuff. Pumice forms the prominent white streaks (fiamme) in the rock (see figure 2 on the accompanying map). These pumice fragments appear as streaks instead of angular blocks because they were flattened as the rock welded and the gas bubbles in the rock collapsed. Although most of the Rhyolite Canyon Tuff is densely welded, relatively thin layers of poorly welded ash and pumice, and surge beds of ash, are visible as horizontal white bands in the cliffs of the National Monument. These white bands mark contacts between distinct sequences of pyroclastic flow deposits. Two such contacts are present within the Rhyolite Canyon Tuff in the National Monument; they divide the tuff into three layers, or members (see figure 3 on the accompanying map). All three layers were erupted in rapid succession. White, ash-rich surge beds are particularly well exposed along the trail to the summit of Sugarloaf Mountain (figure 7B). They record explosions that blasted ash from the volcano at high velocity. The blasts moved laterally along the ground surface, leaving deposits in which beds intersect one 
another at low angles (crossbedding) and larger, heavier grains sometimes overlie smaller, lighter grains (inverse grading). The surge beds along the Sugarloaf trail have been overprinted by chemical banding produced when water boiled in the ash, leaving less-soluble minerals behind in layers, like the residue in a coffee pot. Fossil fumaroles, where water boiled and steam blasted to the surface, are preserved in the ash and the overlying welded tuff along the trail (figure 7A on the accompanying map). These form irregular vertical pipes, which weather to produce sets of interconnected pits in the rock faces. Fine-grained ash material was blown out of the pipes, leaving the coarser grained ash and crystals behind.

The final chapter in the volcanic history of the National Monument is recorded by the dacite lava atop Sugarloaf Mountain. Volcanic rocks that contain about 63-70 percent silica $\left(\mathrm{SiO}_{2}\right)$ are named dacite. Magma of this composition was in the lower part of the magma chamber beneath the Turkey Creek caldera; it was erupted immediately after the Rhyolite Canyon Tuff. But, because the dacite contained less water and volatiles, it did not explode into ash, but was erupted less violently as lava. Many of these dacite lava flows were trapped inside the caldera depression. The source area for the Sugarloaf lava flow is about 6 miles southeast of Sugarloaf Mountain, where similar lava is exposed inside the caldera near Barfoot Peak (see block diagrams C and D on the accompanying map). Lava from this area flowed out of the caldera and down a former valley into the National Monument. The dacite lava is hard rock that is resistant to erosion. Consequently, it was left standing high as the surrounding tuff was eroded. In this manner an area that was once a valley bottom is now the top of Sugarloaf Mountain.

Although the dacite atop Sugarloaf is the youngest volcanic rock in the Monument, caldera development was not yet complete. South of the Monument, the central part of the caldera depression was uplifted, forming a structure known as a resurgent dome, as first dacite and then new rhyolite magma rose into the magma chamber and lifted its roof (see block diagram $\mathrm{C}$ on the accompanying map). Uplift of the central part of the depression created a circular valley, or moat, between the resurgent dome and the edge of the caldera depression. The new batch of rhyolite magma did not erupt as explosively as the Rhyolite Canyon Tuff, instead it leaked out to form lava flows that were confined within the moat. These lavas were highly viscous, and formed flow ramps similar to those seen in the older rocks near Faraway Ranch. These moat lavas are visible to the south from the lookout atop Sugarloaf Mountain. They form the east-west ridge line south of Pinery Canyon, and extend to the south along the crest of the Chiricahua Mountain range. A dramatic exposure of the flow-ramped moat lava can be seen in the hillside above and just south of Downings Pass on the Methodist Camp road, a side road south of the Pinery Canyon road between the National Monument and Portal, Arizona.
The topography of the Chiricahua Mountains, and the appearance of the Turkey Creek volcano has changed dramatically over the past 27 million years (see block diagram $\mathrm{D}$ on the accompanying map). Steep faults cut the rocks and dropped large blocks down to form the San Simon Valley to the east and parts of the Sulphur Springs Valley to the west. The steep-sided Whitetail Valley at the eastern boundary of the Monument (where the paved road to Sugarloaf Mountain and Massai Point turns south after ascending Bonita Canyon) is parallel to a fault zone along which adjacent crustal blocks have repeatedly shifted. The most recent motion appears to have dropped a block on the east side down, forming Whitetail valley and dragging the Rhyolite Canyon Tuff down into the valley, such that the formerly horizontal welded pumice fiamme (white streaks in the rocks) now plunge steeply into the valley, as indicated by the steeply dipping foliation attitudes on the geologic map that accompanies this pamphlet.

High-angle faulting during the past 20 million years is not restricted to the Chiricahua Mountains. This is just a small part of the faulted Basin and Range Province of the western United States. In essence, subduction off the western coast of North America ceased as the former East Pacific ocean ridge ran into the subduction zone. This ended the subduction beneath the region, and the motion of the plates shifted to strike-slip faulting as the San Andreas fault of California came into existence. Because subduction ceased, most volcanism in the southwestern United States waned, and the crust began to extend. Graben blocks dropped to form valleys between mountain ranges. Because the graben blocks are shaped like keystone blocks in the arches of doorways, the adjacent crust could extend, or be pulled apart, as they sank. This is the most common kind of structure in the Chiricahua Mountains. Nearby, in the Pinaleno and Rincon-Santa Catalina Mountains, crustal extension was also accommodated by low-angle faulting, in which adjacent blocks slid laterally as the earth's crust was pulled apart and thinned. Small amounts of basalt magma leaked from the underlying mantle during this extension process, forming the San Bernadino volcanic field along the southeastern flank of the Chiricahua Mountains. Basalt cinder cones, lavas, and small explosion craters of the San Bernadino field are clearly visible from US highway 80 between Rodeo, New Mexico, and Douglas, Arizona.

As noted above, the columns, or pinnacles, for which the National Monument is known, are erosional features that formed as the welded tuff layer was dissected by water and wind. But, why did erosion form such spectacular columns? Geologists agree that systematically spaced fractures, known as joints, played a key role. When walking in the Monument, you will recognize the joint planes both as thin planar fractures or veins in the rock, and by the alignment of columns in rows (figure 5 on the accompanying map). Erosion was "focused" along the joint planes, thereby cutting the tuff into vertical columns. But, how did the joints form 
in the first place? Recent study has shown that contrary to previous ideas, the joints were not produced as the tuff was squeezed and fractured between faults, as if in a vise. If that were the case, one would expect to see a systematic pattern in the orientation of the joints. Instead, the joint directions vary widely and they curve, features that indicate they resulted mainly from contraction brought about by the original cooling of the tuff. Cooling joints form at right angles to surfaces where heat is removed from a lava flow or tuff layer; these are mainly the top and bottom surfaces and the resulting joints are usually vertical planes. The intersection of joint planes form rock columns; consequently, cooling joints are referred to as columnar joints. Columnar joints are common in lava flows; a spectacular example is Devil's Postpile National Monument, in California. They also are seen in welded tuff layers, such as in the rhyolite tuff cliffs of Bandelier National Monument and adjacent to the Gila Cliff Dwellings National Monument, both in New Mexico, as well as here in Chiricahua National Monument.

How old are the columns, and why don't they fall over? Although the welded tuff and its joints are 26.9 million years old, the columns we see are thought to be less than three million years old. This age is based on calculating how much material has been removed from the Rhyolite Canyon basin over the past 26.9 million years to obtain an erosion rate (it works out to about two-thirds of an inch of downcutting per thousand years). Applying this rate to the average column height of 120 feet yields 2.4 million years. Obviously, this is an average rate, it may have been faster during periods of wet climate, and slower when the climate was dry. Surprisingly, the columns are quite strong, and even the "balanced rocks" are not as fragile as they appear. Engineering analysis shows that the columns are well within their mechanical failure limits for static load; they are not about to fail under their own weight. In fact, the 187 -foot-high Totem Pole could be suspended upside-down without breaking. Dynamic failure is much more likely, in which columns would be "knocked over" by a lateral force. Lateral forces occur during earthquakes, but surprisingly, few of the columns appear to have been destroyed by the nearby magnitude 7.2 Pitaicachi earthquake of 1887 , despite widespread damage to buildings in the region. Perhaps, a "tuned" frequency of earthquake ground waves is required to get the columns swaying enough to fall.

\section{GEOLOGICAL POINTS OF INTEREST IN CHIRICAHUA NATIONAL MONUMENT}

A variety of geological points of interest are shown in the figures on the accompanying map. Most of these are directly accessible from roads or hiking trails; a few require cross-country hiking through rugged terrane. Please inquire at the Visitor Center prior to hiking off trails.
An excellent overview of the stratigraphy of Chiricahua National Monument (figure 11 on the accompanying map) can be seen from the hilltop southeast of Faraway Ranch. The Sugarloaf Mountain trail is recommended for: (1) superb exposures of the contact between the middle and upper members of Rhyolite Canyon Tuff, (2) exposures of fossil fumaroles (figure 7 on the accompanying map), (3) viewing the dacite lava remnant at the summit, and for the overviews of the Turkey Creek caldera to the south and older volcanic rocks of Cochise Head to the north.

The Rhyolite Canyon and Sarah Demming trails provide views of the three members of the Rhyolite Canyon Tuff (figure 3 on the accompanying map) and lead to the Heart of Rocks Loop trail where bizarre-shaped rock columns within the tuff are abundant. Joint trends in the Heart of Rocks area curve to produce a domal pattern, which suggests that the tuff accumulated over a hill in this area. Consequently, the joints may have opened more widely and exaggerated the amount of erosion. In this way, more widely separated and oddly shaped columns would have formed in the Heart of Rocks. Excellent exposures of rock columns and joints are also seen from the Massai Point Trail, and the view of thousands of columns from Massai Point is a definite highlight of any visit to Chiricahua National Monument. Hailstone trail is built along the contact between the lower and middle members of the Rholite Canyon Tuff. In places, the trail is littered with marble-like spherulites (figure 8 on the accompanying map) that weather out of the tuff.

The paved road up Bonita Canyon also follows the contact between the lower and middle members of the Rhyolite Canyon Tuff to Bonita Park where red, clay-rich stream sediments from the ancient Monument valley floor are exposed beneath the lower member. Enroute to Bonita Park, road cuts expose the contact between the lower and middle members of the tuff (figure 4 on the accompanying map). From Bonita Park, the road provides access to Sugarloaf Mountain and Massai Point and provides spectacular views into the fault valley of Whitetail Canyon and the eastern flank of the northern Chiricahua Mountains.

\section{GLOSSARY}

accreted-With respect to plate tectonic theory, the process by which continental crust grows through the addition of smaller fragments of crust to its margins. An accreted terrane is a fragment of crust that was transported by plate tectonic processes and added to the margin of a continent. Much of the western United States is composed of accreted terranes.

accretionary lapilli-Lapilli are small, approximately 0.1 - to 2.5-inch-diameter, spherical balls of ash that accrete, or stick, to water droplets or crystals in the ash cloud of a volcanic eruption. They are concentrically layered, like hail balls, as a result of repeated accretion of layers of ash. 
andesite- $\mathrm{A}$ volcanic rock with about 52-63 percent silica $\left(\mathrm{SiO}_{2}\right)$. Commonly contains the minerals hornblende and pyroxene, in addition to feldspar. Like dacite, andesite is a relatively common rock in volcanic arcs. Commonly forms lava flows; andesitic pyroclastic rocks are less common.

ash-Very fine grained and unconsolidated volcanic "dust" composed of broken particles of volcanic glass, crystals, and rock fragments. Commonly dominated by microscopic shards of glass produced by breakage of gas bubbles in the source magma. Tuff rock is composed mainly of consolidated ash and pumice.

ash flow-A dense cloud composed dominantly of hot ash and pumice. Moves rapidly due to liberation of gas from pumice and to ingestion of air at flow front. Produces an ash-flow deposit (tuff), that if sufficiently hot may weld to produce welded tuff. A type of pyroclastic flow.

basalt-A dark-colored volcanic rock with less than 52 percent silica $\left(\mathrm{SiO}_{2}\right)$. Basalt is one of the most common volcanic rocks on earth. It underlies most of the ocean basins, as well as large areas of the continents, such as the Columbia River Plateau of the Pacific Northwest. Basalt is produced by melting of mantle rocks, and eruption of basalt is widely viewed as the principal means of transporting mass and heat from the mantle to the crust.

basement-Rock layers or masses that underlie the rocks of interest; typically more poorly exposed due to burial by overlying rocks.

Basin and Range Province-A physiographic and structural region of the western United States composed of north- or northwest-trending mountain ranges separated by parallel valleys. The Province includes southeastern California, most of Nevada and Utah, and the southern parts of Arizona and New Mexico, as well as extending south into Mexico. Produced mainly during the last 20 million years during extension of the earth's crust after subduction ceased to the west. High-angle faults are typically found along margins of the mountain ranges. Relative uplift of the mountain ranges and subsidence of the valley basins took place along these faults, some of which are still active today.

batholith-A large region of plutonic rocks that have an area that is typically much greater than 40 square miles, such as the granite batholith of the Sierra Nevada in California. Most batholiths consist of many bodies of magma that were intruded during an extended period of time and represent the roots of island arc volcanic complexes.

biotite-A dark-brown, bronze, or black magnesium and iron-rich variety of the group of minerals that are known by the common name "mica." Cleaves into thin sheets, although this characteristic may be difficult to observe in the small grains of volcanic rocks without use of a hand lens and needle probe.

breccia-A sedimentary or volcanic rock composed of angular rock fragments set in a finer grained matrix.
caldera-A volcanic depression larger than a crater. typically circular or elliptical in outline, created by collapse of the roof of a magma chamber and brought about by rapid eruption of magma from the chamber. Calderas associated with the eruption of rhyolite tuff range from about one to as many as 60 miles in diameter. Derived from the Spanish term for a kettle or cauldron. In calderas like Turkey Creek, the floor of the caldera is uplifed to produce a resurgent dome and subsequent lavas accumulate in the annular depression or moat between the resurgent dome and the caldera rim.

Cambrian-The geologic time period extending from about 570 million years ago until about 510 million years ago; the earliest period within the Paleozoic Era, when advanced forms of life first became abundant.

Cenozoic-A geologic era, extending from about 65 million years ago at the beginning of the Tertiary period until the present.

chatoyant-The property of some minerals to produce a distinct reflected color or luster. Produced by reflectance of light by minute internal fibers, cavities, or tubes. The feldspar mineral sanidine in the Rhyolite Canyon Tuff shows this property.

columnar joints-Planar or curvilinear fractures that bound polygonal columns of rock. Typically form due to contraction during cooling of volcanic rocks. Tend to form at right angles to cooling surfaces, therefore are typically vertical, except near valley walls.

Cretaceous - The geologic time period extending from about 135 million years ago until about 65 million years ago.

crossbedding-Bedding in a sedimentary or volcanic rock in which individual beds intersect and truncate one another at outcrop scale. Indicates currents (in either wind or water) that scoured older beds and deposited new beds across the scoured surfaces, leading to truncation of the older beds. With respect to volcanic ash deposits, low-angle crossbedding is indicative of high-energy transport of particles in a lateral fashion, as seen in surge beds.

dacite-A volcanic rock with about 63-69 percent silica $\left(\mathrm{SiO}_{2}\right)$. Commonly contains the minerals hornblende and biotite, in addition to feldspar, and rarely quartz. A relatively common rock in volcanic arcs. Forms lava flows as well as pyroclastic rocks, including ash-flow deposits.

feldspar-The most common mineral group in the shallow levels of the earth's crust. Composed of combinations of potassium, sodium, and calcium combined with aluminium and silicon. The principal feldspar mineral of the Rhyolite Canyon Tuff is sanidine, a potassium- and sodium-rich feldspar of volcanic origin. Feldspar is typically transparent or white, although sanidine may show a secondary blue luster (it is chatoyant).

fiamme-Italian for "flame." Refers to lens-shaped flattened pumice fragments in a welded tuff. In cross-section such fragments commonly have jagged terminations, giving the appearance of flames. In the Rhyolite Canyon Tuff, 
pumice fiamme are typically white and range in size from less than an inch to more than a foot in length and are commonly flattened to disc-shaped bodies with thicknesses less than $1 / 10$ of their diameter. The plates are typically horizontal as a result of flattening (deflation) of pumice blocks by gravity during cooling of the tuff.

flow ramp-A sequence of layers in a lava flow that ramp abruptly upward. Produced in highly viscous materials as shear planes develop. Most common in high-silica (rhyolite) lavas due to their high viscosity.

foliation-A planar aspect of a rock produced by the arrangement of constituent grains or fragments during metamorphism or cooling. In volcanic tuff, foliation is commonly produced by the deflation of pumice blocks under the influence of gravity (see welding). Consequently, the initial foliation plane in welded tuff is generally horizontal and other orientations are usually the result of tilting during episodes of mountain building. Foliation is indicated on a geologic map by a small line segment oriented parallel to the intersection of a horizontal plane with the inclined foliation plane, and with an attached triangle that points down the inclined plane. The adjacent number indicates the dip of the plane in degrees.

formation-The fundamental unit of stratigraphic classification, consisting of rock layers that have common characteristics that allow them to be distinguished from other rocks and to be mapped as separate, generally tabular bodies. Formations are typically named for geographic places, and can be subdivided into members or combined into groups.

fumaroles-Steam vents within volcanic rocks. Result from degassing after deposition of ash-flow deposits, or from formation of steam from underlying wet ground.

graben block-A block of rocks, typically more than several square miles in area and bounded by inwardly dipping fault planes, in which the graben block moved down relative to the adjacent blocks, which are termed horst blocks. A keystone graben is a common configuration, in which the block has the general shape of the keystone block in an archway. Extension may be accommodated by formation of a horst and graben structure in which the grabens move down relative to the adjacent horsts, as would the keystone in an archway, if the arch was pulled apart.

graded bedding - The result of gravitational settling of particles in a fluid which results in larger and heavier grains being concentrated at the base of a deposit. Inverse grading results in larger grains above smaller ones. Inverse grading indicates rapid lateral flowage. Inverse grading is a characteristic feature of surge beds.

granite-A high-silica rock (typically with more than 70 percent silica) composed mainly of coarse-grained crystals of quartz and feldspar. The compositional equivalent of the volcanic rock rhyolite, but cooled slowly at depth so all of the magma crystallized and no glass remains. Magmas that cool slowly and crystallize at depth are termed plutonic rocks. They tend to form large masses of coarse-grained rocks that cover several square miles or more. Where numersous plutons coalesce, the resultant body of plutonic rock. which is called a batholith may cover hundreds of square miles.

intruded-The process by which a magma is emplaced into other rocks. The overlying or adjacent rocks may break. allowing the magma to move into or through it along fractures, or it may be melted and become a part of the advancing magma.

inverse grading-See graded bedding.

island arcs-Arcuate linear belts of volcanic islands that overlie subduction zones. Where such volcanic belts occur within a continental mass overlying a subduction zone, the term volcanic arc is used.

joints-Planar fractures or cracks along which there has been negligible movement. May be produced by cooling (see columnar joints) or by a directed stress due to faulting or folding of the rock.

Jurassic-The geologic time period extending from about 205 million years ago until about 135 million years ago.

Laramide orogeny-A period of mountain building (orogeny) marked by widespread faulting and volcanism at the close of the Mesozoic, about 65 million years ago.

Lisesgang bands-Secondary layers produced in a rock by chemical deposition from a fluid that migrated through the pore space of the rock. Distinguished from primary bedding or layering by lack of change in grain size or proportions of different mineral grains across bands and by cross-cutting relations with primary bedding.

magma-Molten rock, a silicate liquid. Typically contains dissolved volatiles such as water vapor and carbon dioxide and suspended crystals. Common magmas range in composition from basalt, with less than 52 percent silica $\left(\mathrm{SiO}_{2}\right)$ to rhyolite, with more than 70 percent silica.

magma chamber-A reservoir of molten rock beneath the earth's surface. Crystallized magma at depth in a magma chamber produces coarse-grained plutonic rocks, such as granite.

mantle-A division of the layered earth between the core and the crust. The upper part of the mantle is composed of magnesium- and iron-rich silicate minerals, such as olivine and pyroxene. The depth to the mantle varies from less than 6 miles beneath young ocean crust to as much as 60 miles beneath continents. Mantle rocks exist at high temperature and deform slowly in a plastic manner. They flow in response to the broad convection currents that drive plate tectonics. Where these mantle rocks upwell, they begin to melt, yielding magma that can rise toward the surface to fill magma chambers and feed volcanoes.

member-A subdivision of a geologic formation, typically consisting of one or more beds.

Mesozoic-A geologic era, extending from about 250 million years ago at the beginning of the Triassic period until about 65 million years ago, through the end of the Cretaceous period. 
moat-An annular depression between the central resurgent dome and the edge of a caldera depression.

nuée ardente-A "glowing cloud" of hot ash that rises from an avalanche of volcanic ash and rock fragments. The ash cloud and related avalanche are a type of pyroclastic flow produced by the collapse of the oversteepened front of a viscous lava dome and from explosions that emanate from within the underlying magma. These flows generally produce relatively small-volume, ash- and rock-fragment-rich deposits that lack abundant pumice and do not weld. The term was coined to describe the glowing cloud that swept down from the base of the lava dome atop Mount Pelée, Martinique, on May 8, 1902, and killed 30,000 people in the town of Saint Pierre. Subsequent avalanches produced clouds of hot ash that glowed dull red at night.

obsidian-Black or dark volcanic glass that has conchoidal fracture. Valued for use in making sharp-edged rock tools and arrow points. Most of the volcanic glass in the Chiricahua Mountains has been altered by the addition of water along fractures, producing a rock that although still looking outwardly like obsidian, tends to fracture into small fragments, hence, not as useful for arrow points.

Paleozoic-A geologic era, extending from about 570 million years ago at the beginning of the Cambrian period until about 250 million years ago, through the end of the Permian period.

Permian--The geologic period extending from about 290 million years ago until about 250 million years ago.

pillow lava - Lava that flowed under water and formed pillow-shaped masses as a consequence of chilling and solidification of the outer surface while the inner part of the lava flow was still flowing. Usually basalt or andesite; the most common type of lava in oceanic crust.

plutonic-Refers to a coarse-grained igneous rock that crystallized slowly beneath the Earth's surface.

porphyry-A volcanic or intrusive rock that is composed of large crystals within a matrix of finer grained crystals or volcanic glass. The dacite porphyry of the Turkey Creek caldera is both a shallow plutonic rock produced by intrusion of dacite magma into the floor of the caldera shortly after it collapsed and thick lava flows that accumulated in the floor of the caldera moat.

Precambrian Era-A broad division of geologic time extending from initial formation of the earth about 4.5 billion years ago to the beginning of the Cambrian Period about 570 million years ago.

pumice-A gas-bubble-rich volcanic rock; typically with enough bubbles to allow it to float in water. Also used to describe fiamme in welded tuff, which represent pumice blocks that were flattened and deflated during welding.

pyroclastics-Fragmental material produced by a volcanic explosion or eruption.

pyroclastic flow-A dense cloud of hot ash, rock debris, pumice, and gas that moves rapidly downslope from a volcano and leaves an ash-rich deposit (a pyroclastic flow deposit). Pyroclastic flows move rapidly because they are inflated by volcanic gas and by air ingested at the flow front. If sufficiently hot and thick, the resultant deposit may weld. Welded tuff, ash-flow tuff, and nuée ardente deposits are all types of pyroclastic flow deposits.

Quaternary-The geologic time period extending from about 2 million years ago until the present.

resurgent dome-A region of domal uplift within a caldera depression. Caused by intrusion of new magma into shallow levels within or beneath the caldera.

rhyolite-A volcanic rock or magma that contains more than about 70 percent silica. Rhyolite rock is usually light gray or white, but may be black if quenched to glass (obsidian), and it can be a variety of other colors as a result of alteration. Commonly contains crystals of quartz and alkali feldspar. Granite is the slowly cooled and, consequently, coarse-grained plutonic equivalent of rhyolite.

Rhyolite Canyon Tuff-A welded ash-flow deposit composed of rhyolite ash, pumice, crystals, and rock fragments that was erupted from the Turkey Creek caldera about 26.9 million years ago. See the appendix for additional details.

sanidine-A potassium- and sodium-rich type of feldspar mineral. A common crystal in rhyolite lavas and tuffs. Sanidine is typically clear, but may be bluish and chatoyant. It commonly appears cloudy or white when altered.

schist-A metamorphic rock that is rich in the platy mineral mica. The mica grains are aligned by deformation to produce internal layering (foliation) and a shiny appearance to the rock.

shard-A glass fragment, typically produced by the disintegration of bubble walls in pumice. Characterized by curved fracture surfaces.

spherulites - A spherical mass produced by crystallization of volcanic glass at high temperature and typically composed of minute crystal fibers of feldspar that radiate from a common point.

spreading ridges-The globe-encircling submarine mountain range where the oceanic sea floor and crust is created by upwelling and eruption of basalt magma.

stratigraphic unit-A particular rock deposit or group of deposits that are generally similar in composition or type and are about the same age. Stratigraphic units are the fundamental building blocks for constructing geologic maps.

strike-slip fault-A fault or planar surface along which the adjacent blocks of the earth's crust slide horizontally past one another. Contrasts with a dip-slip fault along which motion is dominantly vertical.

subduction-A fundamental component of plate tectonics theory. The process by which oceanic crust is destroyed by sinking into the mantle along an inclined subduction zone. These zones are within the ocean basins and along continental margins where they produce numerous earthquakes as the oceanic crustal plate slides down beneath the adjacent oceanic or continental plate. Subduction zones 
are sometimes marked by ocean trenches, such as the Marianas Trench. Fluids are liberated from the sinking plate as it is heated at depth. These fluids act as a flux to help melt overlying rocks, producing magma that supplies volcanoes on the surface. Volcanic arcs overlie subduction zones, typically in a linear belt or arc; arcs form above the area where the subducted plate reaches a depth of about 60 miles.

surge beds-Ash-rich beds that result from laterally-directed volcanic blasts. Characterized by inverse grading and low-angle crossbedding.

Tertiary-The geologic time period extending from about 65 million years ago until about 2 million years ago.

tuff-A volcanic rock made up of consolidated ash, pumice, and rock fragments, typically derived from a pyroclastic flow but may also include deposits that accumulate from the "rain" of ash and debris after an eruption.

unconformity-A surface separating two formations of distinctly different age, such that a significant period of geologic time is missing from the rock record between the two deposits.

vitrophyre-Dense volcanic glass produced by extreme welding at the base of a welded tuff deposit.

volcanic arc-See island arc.

welded tuff-A tuff, typically produced from a pyroclastic flow that was sufficiently hot and thick for welding to occur.

welding-The process by which all or part of the gas-rich deposit from pyroclastic flows compacts while still hot, due to the weight of the overlying part of the deposit. During welding, gas bubbles in pumice blocks and glass shards are flattened and fused together, gas is expelled, and the deposit becomes more dense.

\section{SUGGESTED ADDITIONAL READING}

\section{GENERAL GEOLOGY}

Cronic, Halka, 1986, Roadside Geology of Arizona: Mountain Press, Missoula, Mont., 321 pages (guide to geologic features in Arizona, introductory level).

Press, Frank, and Siever, Raymond, 1974, Earth: W. H. Freeman and Company, San Francisco, Calif., 943 pages (geology textbook, introductory level).

Rhodes, Frank H. T., 1991, Golden Guide to Geology: Golden Press, Western Publishing Co. Inc., Racine, Wis., 160 pages (overview of geology, introductory level).

Sorrell, C. A., 1973, A guide to field identification of rocks and minerals: Western Publishing Co., Inc., Racine, Wis., 280 pages (field guide, introductory level).

\section{VOLCANOLOGY}

Cas, R. A. F., and Wright, J. V., 1988, Volcanic Successions, Modern and Ancient: Unwin Hyman, Boston, Mass., 528 pages (college level textbook, emphasis on physical volcanology and sedimentology).

de Golia, Jack, 1989, Fire: The story behind a force of nature: K.C. Publications, Las Vegas, Nev., 48 pages (volcanology for the nonspecialist, introductory level).

Harris, Stephen L., 1990, Agents of chaos: Mountain Press. Missoula, Mont., 260 pages (volcanology for the non-specialist, introductory level).

Macdonald, Gordon A., 1972, Volcanoes: Prentice Hall, Englewood Cliffs, N.J., 510 pages (introductory level textbook with narratives of eruptions and numerous examples of volcanologic phenomena).

Williams, H., and McBirney, A. R., 1979, Volcanology: Freeman, Cooper and Company, San Francisco, Calif., 397 pages (college level textbook, emphasis on petrology, physics, and chemistry).

\section{TURKEY CREEK CALDERA}

du Bray, E. A., and Pallister, J. S., 1991, An ash-flow caldera in cross section: Ongoing field and geochemical studies of the Mid-Tertiary Turkey Creek caldera, SE Arizona: Journal of Geophysical Research, v. 96, no. B8, p. 13,435-13,457 (technical paper).

1994, Geologic Map of the Stanford Canyon quadrangle: U.S. Geological Survey Geologic Quadrangle Map GQ-1733, scale 1:24,000, 1 plate (technical geologic map).

1994, Geologic Map of the Chiricahua Peak quadrangle: U.S. Geological Survey Geologic Quadrangle Map GQ-1733, scale 1:24,000, 1 plate (technical geologic map).

du Bray, E. A., Pallister, J. S., and Yager, D. B., 1997, Geologic map of the Turkey Creek caldera, Chiricahua Mountains, Cochise County, Arizona: U.S. Geological Survey Miscellaneous Investigations Map I-2544, scale $1: 50,000,1$ plate (technical geologic map of the entire caldera).

Pallister, J. S., and du Bray, E. A., 1989, Field guide to volcanic and plutonic features of the Turkey Creek caldera, Chiricahua Mountains, southeast Arizona, in Chapin, C. E., and Zidek, J., eds., Field excursions to volcanic terranes in the western United States, Volume I: Southern Rocky Mountains region: New Mexico Bureau of Mines and Mineral Resources Memoir 46, p. 138-157 (field trip guidebook, college level, for the professional geologist or student).

1994, Campground talk and slide show on volcanoes for Chiricahua National Monument: U.S. Geological Survey Open-File Report 94-232, 13 p. script and 42 slides (introductory level overview of the volcanic geology of Chiricahua National Monument with comparisions to the eruptions of active volcanoes).

1994, Geologic Map of the Fife Peak quadrangle, southeast Arizona: U.S. Geological Survey Geologic Quadrangle Map GQ-1708, scale 1:24,000, 1 plate (technical geologic map). 
Pallister, J. S., du Bray, E. A., and Latta, J. S., IV., 1994, Geologic Map of the Rustler Park quadrangle, southeast Arizona: U.S. Geological Survey Geologic Quadrangle Map GQ-1696, scale 1:24,000, 1 plate (technical geologic map).

\section{APPENDIX. NONTECHNICAL DESCRIPTION OF MAP UNITS}

[Symbols are abbreviations for the map unit names given in the Technical Description of Map units. These consist of a capital letter, which refers to the geologic age, such as $\mathbf{T}$ for Tertiary, followed by lower case letters, which refer to the rock type, such as rc for Rhyolite Canyon Tuff. The map units are presented in order of youngest to oldest.]

Qal

Qaf

Qc

QTIs

Tcg

Tmt3

$\mathrm{Tmr2}$

Tmt2

Tmr1

Tmt1

Tdpl Dacite lava-Preserved only as the remnant of a

Trco

Trcu

Trcm

Trcl lava flow atop Sugarloaf Mountain. The lava may have flowed down an ancient valley from near Barfoot Peak, southeast of the National Monument (see block diagram C, on map). About 26.9 million years old

These are various subdivisions of sand, silt, and gravel. Where these materials are thick, such as in valley bottoms, they are shown as separate map units; where they are thin, the underlying basement rock is shown on the geologic map. Most of these materials were derived from weathering of older rocks during the past 2 million years, hence they are of Quaternary age; however, some landslide and conglomerate deposits may be older than 2 million years, and they are assigned a Tertiary age

Moat deposits-Mainly lava flows, relatively thin ash- and pumice-rich deposits (pyroclastic flows or tuffs), and lesser amounts of sedimentary rocks that were deposited within the Turkey Creek caldera, between the uplifted central region and the caldera wall (the moat of the caldera). Most of these rocks are rhyolite in composition and were originally composed of volcanic glass that contained few crystals. They are now mainly light gray, rather than black (like obsidian), because the glass crystallized to fine-grained minerals. These rocks are between 26.6 and 26.9 million years old

hyolite Canyon Tuff-A welded ash-flow deposit composed of rhyolite ash, pumice, crystals, and rock fragments that were erupted from the Turkey Creek caldera about 26.9 million-years-ago. This material was

transported by hot ash-rich clouds (ash flows) and accumulated to a thickness of more than 1,600 feet in an ancient valley and basin in the area of Chiricahua National Monument. The tuff chilled to produce dense black volcanic glass (vitrophyre) at its base and compacted (welded) while still hot to produce dense rock. It is distinguished in the field by abundant white streaks, which represent flattened pumice blocks (figure 2 on the accompanying map), and by small quartz and feldspar crystals. The feldspar has a bluish luster in sunlight (it is chatoyant). Where possible, the Rhyolite Canyon Tuff is subdivided into lower, middle, and upper members (figure 3 on the accompanying map).

Jesse James Canyon Tuff-Another welded ash-flow deposit that was deposited shortly before the Rhyolite Canyon Tuff in an ancient valley in Chiricahua National Monument. Reaches a thickness of 790 feet near Jesse James Canyon. Also rhyolite in composition and difficult to distinguish from Rhyolite Canyon Tuff in the field.

Tfre

Tfpe

Tfrh

Tfph

Tbp

Tjg

Tim 
Tr Rhyolite dikes-These are narrow vertical sheets of rhyolite that cut across other map units and represent the passageways through which rhyolite magma was transported.

Kbls

$\mathrm{Km}$

$\mathrm{Kg}$

Bisbee Group-An assemblage of sedimentary rocks of Cretaceous age (about 100 million years old). Sedimentary rocks in the Bisbee Group are conglomerate, sandstone, siltstone, and limestone.

KJV Volcanic and sedimentary rocks-Lava flows and sedimentary rocks rich in volcanic debris. The lavas are dark andesite and basalt, some of which show evidence of eruption under water (as pillow lavas). These Cretaceous and Jurassic rocks are well exposed along the road to Onion Saddle, southeast of Chiricahua National Monument.
Phu

Paleozoic sedimentary rocks-A thick sequence of mainly limestone and dolomite and lesser amounts of sandstone, siltstone, and quartzite of Permian age (about 280 million years old) exposed in the northeastern part of the National Monument. Many of these rocks contain fossils, which represent the ancestors of modern snails, clams, and starfish. These rocks are part of a much thicker section of Paleozoic rocks exposed north and east of Chiricahua National Monument that are as old as about 520 million years and that overlie Precambrian rocks. 


\section{.}




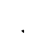


